${ }^{3}$ Fenton, F. R., Tessier, L., Struening, E. L., Smith, F. A. \& Benort, C. (1982) Home and Hospital Psychiatric Treatment. London: Croom Helm.

${ }^{4}$ Hoult, J., Rosen, A. \& ReYnolds, I. (1984) Community orientated treatment compared to psychiatric hospital orientated treatment. Social Science and Medicine, 18, 1005-1010.

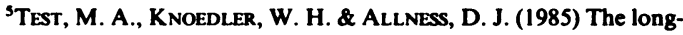
term treatment of young schizophrenics in a community support program. In The Training in Community Living Model:
A Decade of Experience. New Directions for Mental Health Services, no. 26 (Eds L. I. Stein \& M. A. Test) San Francisco: Jossey-Bass.

${ }^{6}$ Platt, S. D., Knights, A. C. \& Hirsch, S. R. (1980) Caution and conservatism in the use of a psychiatric day hospital: Evidence from a research project that failed. Psychiatry Research, 3, 123-132.

A full list of references is available from the authors on request.

\title{
Miscellany
}

\section{New and re-launched journals}

Sexual and Marital Therapy is the official journal of the Association of Sexual and Marital Therapists. It is an international journal for professionals from all disciplines who are concerned with helping people with marital and sexual difficulties. It publishes original research, review articles, therapeutic innovations, counselling techniques and leading comments by authorities on the subject. Short communications, book reviews and a critical review of recent literature are also included. There is a discount of $50 \%$ on the subscription rate for individuals. Readers of the Bulletin can receive an order form and free inspection copy of the latest issue of the journal by writing to the publishers: Carfax Publishing Company, PO Box 25, Abingdon, Oxfordshire OX14 3UE.
The Irish Journal of Psychotherapy and Psychosomatic Medicine was re-launched in September 1987. It began in September 1982 as the Irish Journal of Psychotherapy, was published for three years, and has now recommenced with expanded title and concept to encompass general psychiatric and psychosomatic topics. The Journal will accept relevant original articles, review articles, case reports, book reviews and letters to the editor when manuscripts are prepared in accordance with the Vancouver style. Instructions to authors are given in Volume 4, No. 1, September 1987. It is published twice yearly in March and September. Subscription rates are IR10.00 annually. Submissions and correspondence should be sent to the Editor, Irish Journal of Psychotherapy and Psychosomatic Medicine, St Brendan's Hospital, Rathdown Road, Dublin 7, Republic of Ireland.

\section{New title for Cruse}

Cruse, formerly the National Organisation for Widows, Widowers and their Children, has become CruseBereavement Care. Founded in 1959 to help younger widows with children, Cruse's help-through counselling, advice and information on practical problems and opportunities for social contact-is now available to all those bereaved by death.

Bereavement Care journal is published by Cruse three times a year for all counsellors and others who wish to deepen their understanding of bereavement. It is available on subscription only (1988 subscription in UK: $£ 4.65$, including postage).

Further information: The Information Officer, Cruse, Cruse House, 126 Sheen Road, Richmond, Surrey TW9 IUR.

\section{Award}

Dr Simon Wilkinson has recently been awarded the first Merck prize for research in child psychiatry. This prize is awarded under the aegis of the European Society of Child and Adolescent Psychiatry for "the distinction of extraordi- nary work in the range of child and adolescent psychiatry" by those under $\mathbf{4 0}$ years old. The title of Dr Wilkinson's paper was 'Pretend Illness': an analysis of how communication patterns foster particular forms of complaining. 